\title{
TRIASSIC IGNEOUS ROCKS IN THE VICINITY OF GETTYSBURG, PENNSYLVANIA ${ }^{1}$
}

BY GEORGE W. STOSE AND J. VOLNEY LEWIS

(Rearl before llie Society December 29, 1915)

\section{CONTENTS}

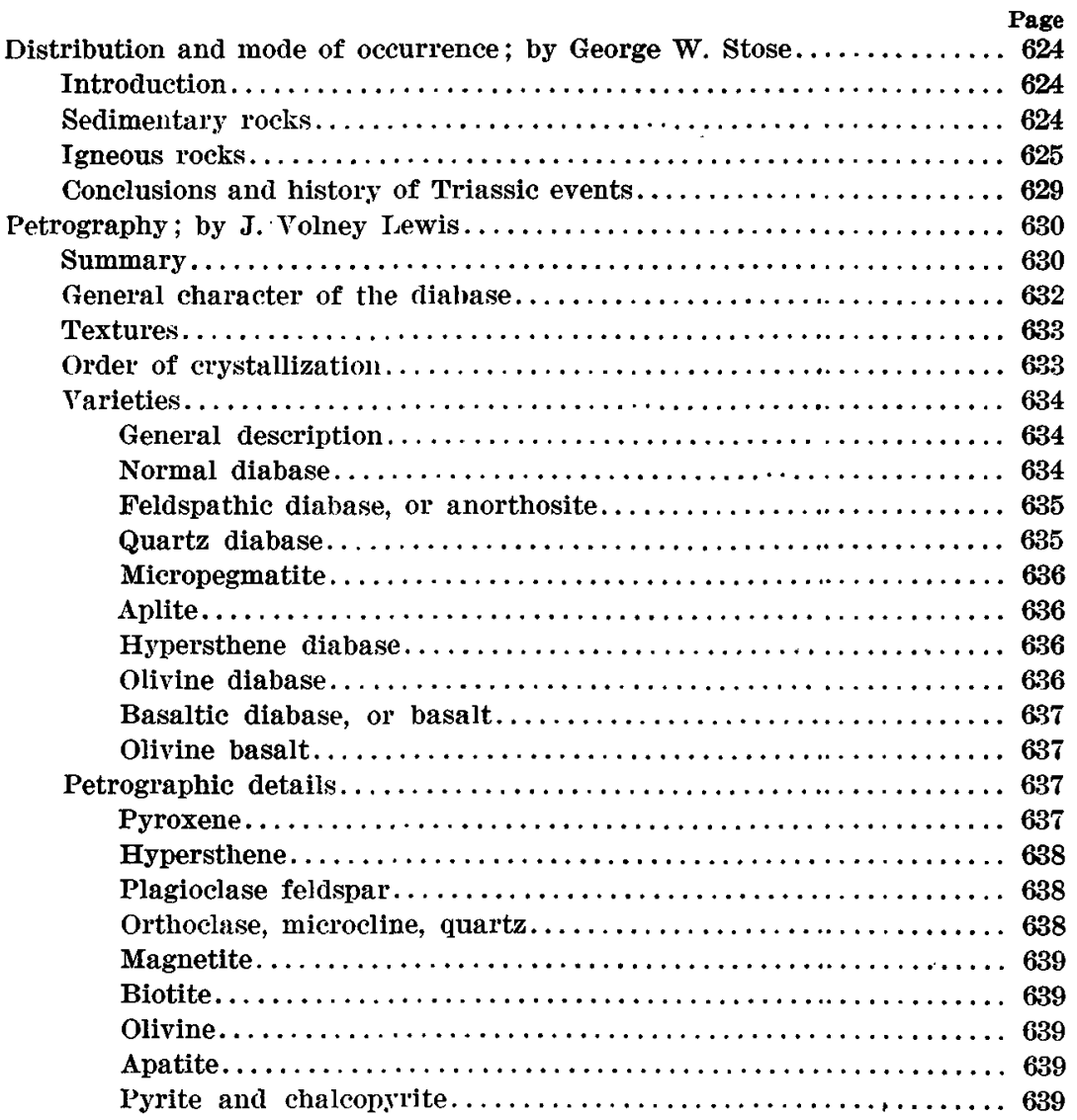

1 Manuscript received by the Secretary of the Society May 12, 1916 .

Published by permission of the Director of the U. S. Geological Survey. 


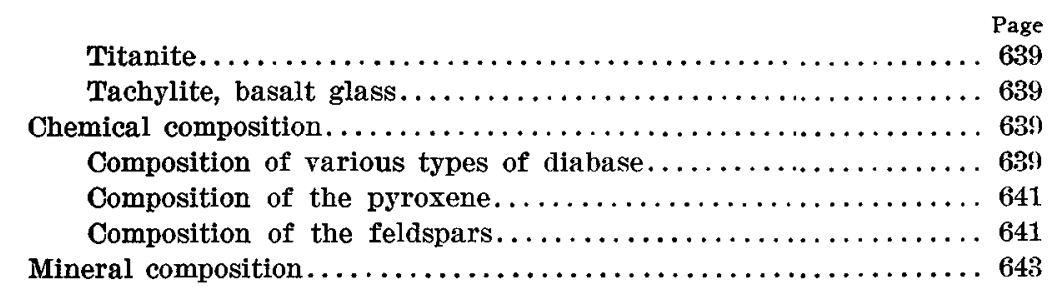

\section{Distribution and Mode of Occurrence; by Glorgie W. Stosle}

\section{INTRODUOTION}

The area here described and shown on the map (figure 1) covers the Fairfield, Gettysburg, and Carlisle quadrangles and the immediately adjacent region. These three quadrangles were surveyed by the writer for publication in folios of the geologic atlas of the United States. The mapping of the adjacent region is taken from published State geologic maps of Maryland and Pennsylrania somewhat modified.

The Triassic igneous rocks of this area, with the possible exception of a thin sheet just south of Bendersville, are all intrusive diabase and include one large sheet, several cross-cutting bodies, and many small sheets and dikes. Their distribution is shown on the accompanying map, figure 1. The concealed and weathered condition of the exposures make it difficult to determine the mode of occurrence of some of the masses, but the relations shown in the sections (figure 2) are probably correct for the portions near the surface. The vent shown on the sections through which the molten magma is believed to have ascended is of course hypothetical, but is based on the facts described and the conclusions reached in this paper.

\section{SEDIMENTARY ROCKS}

The Triassic sedimentary rocks of this area almost invariably strike northeast and dip northwest from $10^{\circ}$ to $35^{\circ}$, with an average of $15^{\circ}$ to $20^{\circ}$. Along the western border, although local pronounced dips were observed, the bedding is on the whole nearly horizontal. The lower beds at the east are red micaceous sandstones and sandy shales interbedded with harder light-gray micaceous sandstones and arkose. At and near the base there are a few thin beds of quartz conglomerate, limestone conglomerate, and black fissile shale. This division is the representative of the Stockton formation of eastern Pennsylvania and New Jersey. The middle portion is chiefly soft red shale. The upper portion comprises both hard and soft red sandstones and shale and harder gray sandstone, culminating at 
the west in coarse quartzose conglomerate and limestone conglomerate. These two divisions probably represent the Brunswick shale of eastern Pennsylvania, as the Lockatong type of sediment apparently does not reach this region, but ends south of Pottstown, Pennsylvania, as described by A. C. Hawkins. ${ }^{2}$ The Triassic is abruptly terminated on its western edge by a normal fault.

Assuming that the beds are not repeated by faulting, as no evidence of strike faults was observed within the Triassic of this area, it is computed from the dip of the beds that there is represented here 23,000 feet of strata, but at no place in the area does this thickness occur. At the western edge of the basin, where, because of the continuous westward dip of the beds across the basin and the great drop fault, the greatest thickness of strata should be expected, the Triassic deposits are very thin, and the limestone floor on which they rest is exposed in the lowlands near York Springs and about Fairfield for nearly 3 miles horizontally under the Triassic. Although the floor of the basin is believed to descend much more rapidly east of these places, as shown in the sections (figure 2), nowhere in the basin will the thickness of the beds approximate the total thickness of the deposit, because the beds successively overlap westward on the limestone floor.

\section{IGNEOUS ROCKS}

The main igneous mass in the area is the great Gettysburg sill, which begins at Emmitsburg, Maryland, a short distance south of the Pennsylvania line, passes northeastward near Gettysburg, and ends a short distance east of Dillsburg. It has an average width of over 1 mile and expands to over 2 miles in places. By its relations to the sedimentary rocks it is shown to be a sheet intrusive in the westward dipping strata, its upper surface being clearly exposed in the Gettysburg battlefield reservation dipping $20^{\circ}$ northwestward under the shale. Its general thickness is about 2,000 to 2,500 feet. That the sheet is somewhat cross-cutting, however, is indicated by the fact that it gradually rises in its position in the beds southwestward, as shown by the stratification lines on the map and by minor irregularities of its outline and width, which are believed to be due to cross-cutting. Some of the more regular offsets, as those east of Gettysburg, are probably caused by faulting. The marked expansion in width in the northeastern part of the Gettysburg quadrangle is apparently a local thickening of the sill, accompanied by cross-shearing of the sedimentary beds and greater uplift of the covering strata.

${ }^{2}$ A. C. Hawkins : Lockatong formation of the Triassic of New Jersey and Pennsylvania. Annals N. Y. Acad Sci., vol, xxili, 1914, pp. 145-176. 
A large cross-cutting body near the south end of the Gettysburg sill, about 1 mile thick, cuts the strata at right angles and extends northwestward nearly to the western edge of the Triassic basin. From this cross-cutting body several sills are sent out. One forms the loop of in-

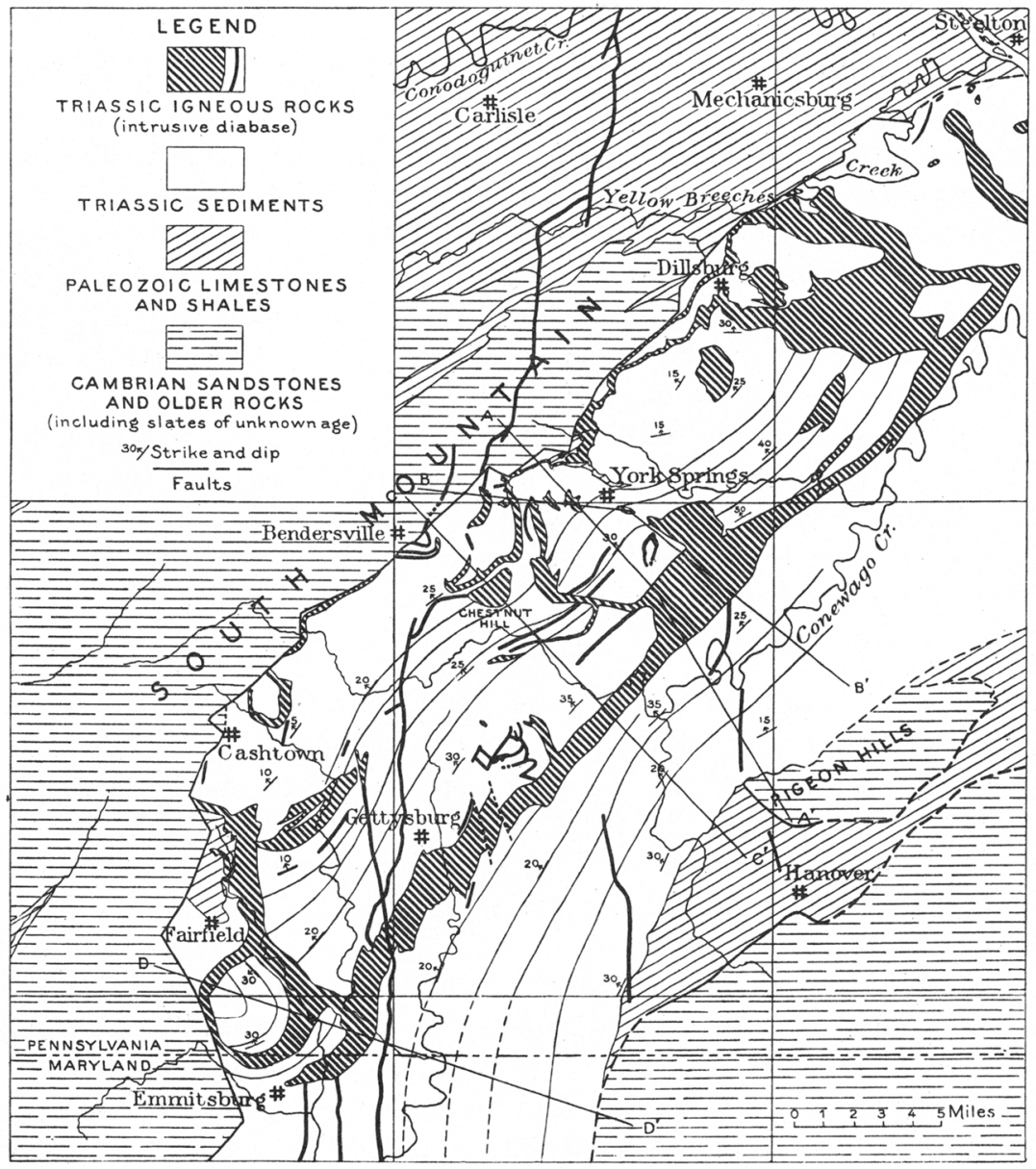

Figure 1.-Geologic Map of the Vicinity of Gettysburg, Pennsylvania

Includes the Fairfield, Gettysburg, and Carlisle quadrangles and portions of adjacent areas. The fine lines in the area of Triassic sediments represent distinct sedimentary layers that have been traced.

trusive diabase north of Emmitsburg - a sheet folded into a basin shape (see section $\mathrm{D}^{-\mathrm{D}^{\prime}}$ ). It is, however, cross-cutting in part, as shown by the truncation of the stratification lines on the map. On the northeast 
it is still united with the cross-cutting mass. Two sills leave the crosscutting mass north of Fairfield. One extends northeastward between the bedding planes and appears to divide into 3 sheets, inclosing sedimentary layers in part of its course. The other lies west of the cross-cutting body and follows the flat contact of the overlapping Triassic sediments on the Paleozoic limestone. This sheet is apparently of wide extent and, although it rises somewhat into the sedimentary beds of the Triassic in places, it is generally at or close to the overlap contact and will be hereafter referred to as the "overlap-contact sill." This relation is well shown in the isolated igneous mass resting on the limestone north of Fairfield. At the western edge of the basin this sill is cut off by the bounding normal fault and is concealed beyond to the north. The loop of cliabase northeast of Cashtown is a folded sheet apparently at a slightly higher horizon, but the band exposed along the western edge of the Triassic farther northeast is probably the outcrop of the overlap-contact sill. 'Tle' narrow loops of diabase at Bendersville are thin folded sheets apparently higher above the base, and one of them seems to be a surface flow. The overlap-contact sill is identified again in the valley northwest of York Springs, where it rests on the Paleozoic limestone floor.

A short cross-cutting body leares the upper side of the Gettysburg sill 5 miles northeast of Gettysburg, and a longer one branches off 5 miles farther on. The latter sends off several small sheets between the sedimentary layers on both sides, and at its western end, where it swells to greater dimensions, a larger intrusive body leaves it and runs northward. This body is believed to be a sheet which is extensively exposed also in adjacent valleys to the west and east and is there overlain by thick beds of conglomerate. Since the conglomerate is known to overlap the Paleo\%oic limestone floor nearly horizontally from the western border of the Triassic to York Springs in a near-by valley, it is believed that the limestone floor lies only a short distance below the intrusive sheet just discribed, which is even nearer the western border, and that this sheet is the same as the overlap-contact sill which was traced northward from Fairfield. This is borne out by the fact that one of the areas of its outcrop connects at the north with the overlap-contact sill that lies on the I'aleozoic limestone floor northwest of York Springs.

The cliabase sill northwest of York Springs follows the limestone outcrop northward to where it disappears along the bounding fault. From there it passes northeastward toward Dillsburg, dividing into two bands. one terminating in the cross-cutting mass that extends east from Dillsburg, the other continuing past Dillsburg to another large cross-cutting borly. These two cross-cutting bolies unite into one large mass which 
forms the northern limit of the intrusive mass and connects with the north end of the Gettysburg sill.

The main intrusive body is thus seen to have the general form of a great trough that comes to the surface on the east as a great sill between the sedimentary strata and on the west as a sill along the flat overlap
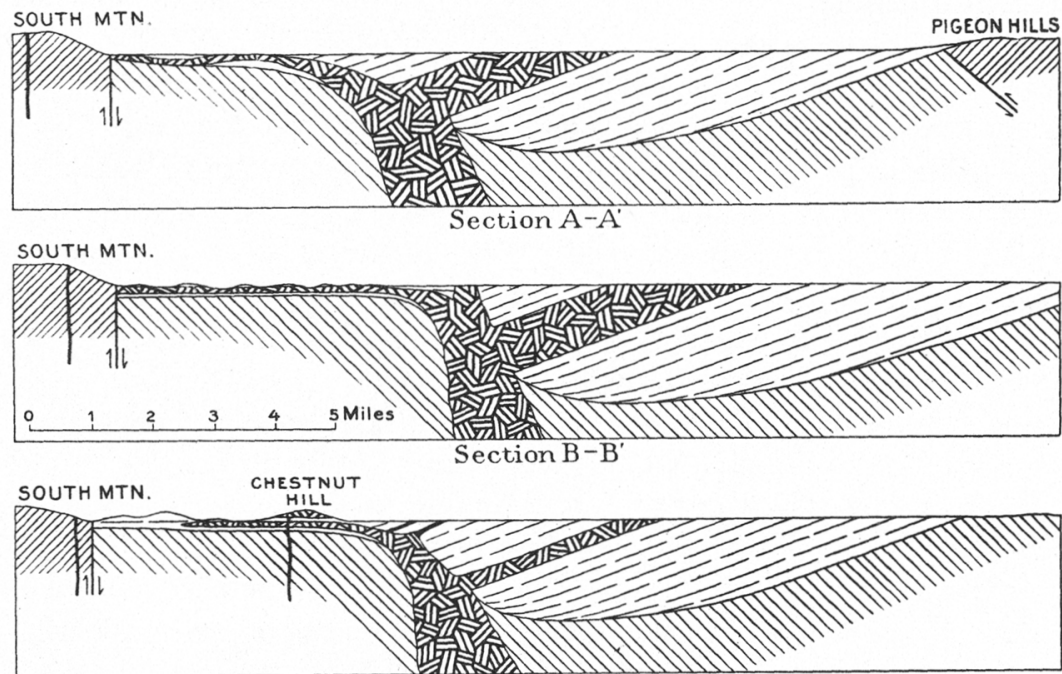

Section $\mathrm{C}-\mathrm{C}^{\prime}$

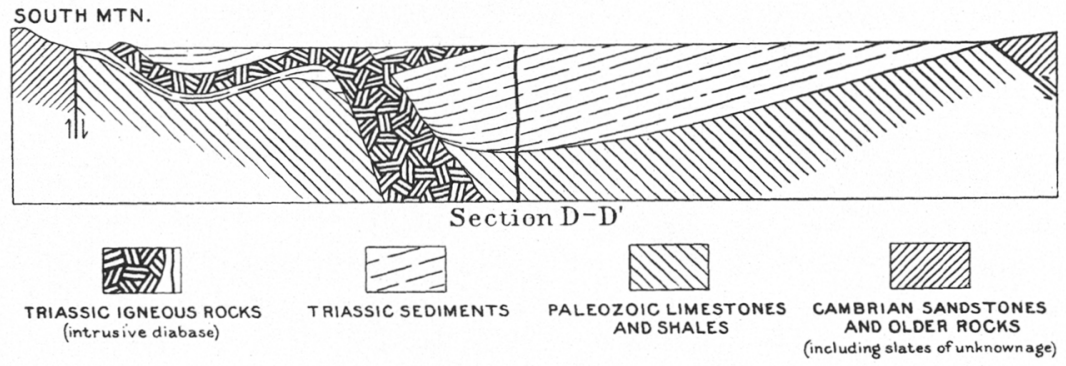

FIGURE 2.-Sections across the Triassic Rocks of the Gettysburg Area

The sections are along the lines marked on figure 1 , and show the structural relations of the formations and the vent up which the igneous rock is supposed to have come into the basin. The vertical scale is somewhat exaggerated.

basal contact, and terminates at the ends in large cross-cutting bodies (see figure 2). That the trough is not complete throughout the area, however, is shown by the absence of the sill at the basal contact in the immediate vicinity of York Springs, where the Paleozoic limestone floor is overlain by Triassic sediments.

The Chestnut Hill igneous mass is a diabase sheet at a higher horizon, 
apparently fed by the dike that joins it on the west. Its present shape suggests that it was of small lateral extent and relatively thick, so that it was of laccolithic habit; but since none of its cover is preserved this can not be positively determined.

There are many dikes and thin sills that cut the sedimentary rocks, some of which seem to connect with the Gettysburg sheet or the crosscutting bodies; but others cut these rocks and are therefore of slightly later age, probably representing the last outburst of igneous activity from the same source. The dikes follow joint fractures, but no system seems to prevail, although the great number, especially the longer ones, trend nearly morth and south. A network of such dikes and sheets occurs 3 miles northeast of Gettyslourg. A chain of uearly continuous nortlısouth dikes of great length crosses the area. The northern one of thesc dikes, which leaves the overlap-contact sill west of York Springs, has been traced across South Mountain into the Cumberland Valley and is known to continue across North Mountain-a distance of at least 25 miles. Another dike, whose comnection with the former is not established, rums south from Chestnut Hill and joins the Gettysburg sill-about 15 miles distant. A third dike in the chain leaves the south ond of the Gettysburg sill and has been traced for 40 miles across Maryland. These three dikes and their intrusive connections have a total length of about 90 miles.

\section{CONCLUSIONS AND HISTORY OF TRIASSIC EVENTS}

It is believed from a detailed study of the rocks and their relations that the progress of Triassic events was somewhat as follows: The sedimentary rocks were deposited in a sinking basin not directly connected with the sea; the sinking began in the southeast and progressed northwestward, so that the center of the basin of sedimentation shifted nortllwestward with the progressive sinking and the sediments overlapped on the Paleo\%oic limestone floor in that direction, the beds being tilted uniformly westward by the progressive sinking. The deepest part of the basin at the close of sedimentation was near the northwestern side, where the latest sinking had occurred, but not at the extreme northwest elge of the basin where the sediments are now seen overlapping nearly horizontally on the flat limestone floor and apparently have not been tilter by sinking The sinking of the basin was accompanied by fracturing and probably faulting of its floor, particularly where the greatest sinking orcurred. The progressive sinking of the basin and the later great ilepression of the block by drop faulting along its northwest edge were due to a lack of support from the rocks beneath, caused by internal movements of readjustment of equilibrim. This condition was accompanied by a re- 
duction of pressure within the deeper-seated rocks sufficient to permit some of them, whose temperature was above their melting points, to liquefy. The molten material, still under pressure, but now free to move, followed the line of least resistance-upward in the zone of reduced pressure - and made its way along the joints, crevices, and fault-planes in the floor of the Triassic basin into the Triassic sediments. Here it wedged in between the northwestward-dipping beds and formed a great sill, while part of it ascended along the northwest base of the sediments between them and the flat floor of Paleozoic limestone, forming another great sill. The overlying strata between these sills was at the same time broken through by great cross-cutting bodies of the igneous mass and by smaller bodies that followed joint planes in the form of dikes. The elongated vent up which the molten magma came was probably at the western margin of the more deeply sunken portion of the basin, where the latest fracturing and faulting of the floor of the basin would have occurred. The further sinking of the Triassic basin resulted in a great irregular fracture along its northwestern side, along which the whole Triassic block settled several thousand feet, carrying the Paleozoic limestone floor far below the base of the Cambrian quartzites of South Mountain.

It seems probable that the molten rock of the large sheets and crosscutting bodies must have reached the surface, unless the thickness of Triassic sediments was much greater than is supposed, and poured out as lava, as it did in the northeastern part of the Triassic basin in New Jerscy; but such surface flows, if they did exist in this area, have been removed by the later erosion that carried away the higher sedimentary beds. A possible exception is found in the western edge of a thin sheet that reaches the boundary fault one-half mile south of Bendersville-the midthe one of the three small concentric sheets. Here the igneous rock is basaltie, in part highly resicular, and much decomposed; and there is a gradation from this to red shale in which are imbedded only scattered fragments from the disintegrating ledge.

\section{Petrography; By J. Volnhy Lewis}

\section{SUMMARY}

The igneous rocks are dominantly diabasic, but show a remarkable diversity of differentiation facies and a corresponding variety of physical characteristics. They range from coarse-grained granitic texture and pink to light or dark gray colors in the larger bodies to dense black rock in the contact facies and in thin sheets and dikes. 
'The chief constituents are a greenish black pyroxene and a whitish to gray plagioclase, largely andesine-labralorite. The pyroxene generally preponderates, but at many places feldspar is approximately equal in amount and locally it is in excess. The microscope shows plentiful magnetite, minute apatite crystals, and generally some quartz and orthoclasethese latter very commonly in micrographic intergrowtl. Locally in the darker varieties there is much hypersthene or olivine or both, while in the lighter facies quartz and orthoclase abound. Here and there biotite is observed and, far less commonly, titanite.

Not uncommonly the pyroxene is altered in part to uralitic amphibole or to serpentine and chlorite with granular magnetite. The corresponding alteration of the feldspars yields fine scaly (apparently sericitic) aggregates and, less commonly, kaolin. In places epidote is abundant.

The texture is typically diabasic-the pyroxene filling angular interstices in a felted ground-mass of slender plagioclase feldspar crystals. By the coalescence of the pyroxene into larger areas, in which the feldspars are imbedded, the texture becomes ophitic. Dense varieties grade into typical basalt with glassy ground-mass-some with scattered phenocrysts of pyroxcne and, in places, feldspar and olivine. In the more acid facies of the rock there is much quartz and orthoclase, either in separate grains or in micrographic intergrowth or both. These occupy angular spaces among the plagioclase crystals and there is much less pyroxene.

The order of crystallization is prevailingly diabasic - that is, the plagioclase was completed before the pyroxene - but there are two marked exceptions: (1) Pyroxene forms prismatic crystals in some of the coarser quartz-orthoclase facies of the rock, in which plagioclase is a subordinate constituent: (2) there are pyroxene phenocrysts in the dense black dikes, thin sheets, and contact facies, in which feldspar phenocrysts are few. Thus the carlier cristallization, probably antedating the intrusion, followed the ustal order in plutonic rocks and would hare produced a gabbro. In the normal diabase the order has been: (1) Apatite, (2) magnetite, (3) olivine, (4) plagioclase, (5) pyroxenc, (6) micrographic quartz and orthoclase, ( $(\tilde{\tau})$ orthoclase, (8) quart\%.

The varieties described are: (1) Yormal diabase, the most common pyroxene-plagioclase rock; (2) felds/allic diabase, or anorthosite, chiefly plagioclase feldspar; (3) quartz diabas', with abundant quartz, much of it in micrographic intergrowth with orthoclase; (4) micropegmatite, consisting in the main of micrographic cullirtz and orthoclase; (5) aptite, essentially a dense granular yuartz-orthe clase rock; (6) hypersthene diabase, with much hypersthene, replacing in part monoclinic pyroxene; $(7)$ olivine diabase, with abundant olivine; (8) basaltic diabase, or basalt, 
dense black facies, in places vesicular and having a glassy ground-mass; (9) olivine basalt, the dense black variety, with abundant olivine.

The areal distribution and delimitation of these varieties can not be determined without much more detailed work in the field and the aid of great numbers of thin sections-work that is out of the question, even if desirable, at the present time. Furthermore, the boundaries, in part at least, would have to be drawn arbitrarily, since gradational facies exist in some places, as shown by thin sections already in hand.

Strongly contraster facies are apparently closely associated in places, as in the occurrence of highly feldspathic along with olivine-bearing basaltic types southeast of Bendersville. In the larger bodies the probability of some gravitational differentiation seems to be indicated, similar to that observed in the Palisades of the Hudson. This is particularly true of the Gettysburg sheet, where acid feldspathic and quartzose facies seem to dominate in the middle and upper (westerly) parts, although not to the exclusion of some more basic rock, while black, heary hypersthenic and olivinic facies are typically developed near the bottom along the easterly contact. The outcrops here, however, are neither so continuous nor so fresh as in the Palisades, and the extent to which such differentiation has occurred would be difficult to determine.

\section{GENERAL CHARACTER OF THE DIABASE}

The larger intrusive masses, both in the sheets and the cross-cutting bodies, present a different appearance in the main from the dikes and thin sheets, although they are obviously parts of the same original magma. Indeed, some of the most strongly contrasted types are parts of one continuous mass, and all of them are doubtless united in a similar manner at no great depth. As a rule, the larger bodies of diabase are coarse grained, with colors ranging from light pink and gray to dark gray, and some of it is quarried and marketed as granite. The dikes and thin sheets, on the other hand, are fine-grained to dense rock and are nearly black.

In normal diabase, which is the prevalent type, the most important constituents are greenish black pyroxene and a white or grayish plagioclase. The pyroxene commonly preponderates, but in many places the two minerals are approximately equal and locally the feldspar is in excess. Crystals and irregular grains of magnetite and minute slender needles of apatite are rather plentiful and there is generally a little quartz and orthoclase. The darker varieties of the rock contain locally much hypersthene or olivine or both, while in the lighter facies quartz and orthoclase abound-as a rule, intergrown in greater part as micropegmatite. Here and there biotite is present in much smaller amount and, far less commonly, titanite. 
The pyroxene is rather commonly altered in part to uralitic amphibole, serpentine, or chlorite, generally with more or less granular magnetite. A corresponding partial alteration of the feldspars has given rise to fine, scaly, apparently sericitic, aggregates and less commonly to kaolin. In places epidote is also an abundant secondary constituent.

\section{TEXTURES}

The size of the mineral grains in the rock has undoubtedly been determined in the main by the rate of cooling of the magma. Thus the coarser rock occurs largely in the thicker portions, which retained their heat and took much longer to crystallize than the thin sheets and dikes. In the very coarse quartz-bearing facies, however, the degree of liquidity has also been an important factor. These portions of the rock doubtless represent the last remnants of the magma which had become highly fluid, perhaps almost a watery solution, by the concentration of the volatile constituents from much of the adjacent magma that had crystallized earlier. The dikes and thin sheets are even denser, as a rule, than the contacts of the larger masses, and some of them are so homogeneous in appearance that their igneous character is not readily detected, even with a hand lens, although it may generally be inferred from the greater weight of the rock in comparison with the dense black variety of shale.

In the typical'diabasic texture the angular spaces among the interlacing lath-shaped plagioclase crystals are occupied by pyroxene. With increasing proportions of the latter mineral it forms larger continuous areas in which the feldspars are imbedded, producing the ophitic texture. These textures are visible in hand specimens of the coarser varieties; but in the finer grained and dense varieties the aid of the microscope is required, and the thinner dikes and sheets show all gradations to typical basalt with glassy ground-mass. Scattering phenocrysts of pyroxene and, less commonly, of feldspar and olivine are developed in some of these denser facies. In the varieties containing much quartz and orthoclase, whether in separate grains or in micrographic intergrowth, these minerals occupy most of the angular spaces among the plagioclase feldspars and there is much less pyroxene. With increasing abundance of quartz, orthoclase, and the micrographic intergrowth of these minerals in approximately cquidimensional grains, there is a falling off of plagioclase and the texture becomes granitoid.

\section{ORDER OF CRYATA LLIZATION}

From the diabasic texture of most of the rock, it is obvious that the crystallization of the plagioclase feldspar was quite generally completed 
before that of the pyroxene. To this general rule there are, however, two exceptions: (1) In some of the coarser grained feldspathic and quartzose facies of the rock, in which orthoclase is the chief feldspar and plagioclase is much less abundant, the pyroxene has a well developed prismatic form and has evidently preceded the bulk of the feldspar in crystallization. (2) The common occurrence of pyroxene phenocrysts in the finegrained contact facies of the larger intrusives and in the dense black dikes and thin sheets, with only here and there a large feldspar, indicates that the conditions of earlier crystallization, probably antedating intrusion, would have led to the completion of the pyroxene before the feldspar and the production of a rock of gabbroic texture.

Apatite and magnetite show by their crystalline form and their indifference to the other minerals that they were among the first products of crystallization. Here and there an inclusion of apatite in magnetite shows that the former mineral preceded the latter. Olivine, where it occurs, came before both the pyroxene and the feldspars, in both of which it forms inclusions. Orthoclase and quartz were the last constituents to crystallize-first in micrographic intergrowth, where this was formed, and then as separate grains of the two minerals, with quartz alone filling the last interstices. The prevailing order of crystallization in these rocks may be enumerated therefore as follows: (1) Apatite, (2) magnetite, (3) olivine, (4) plagioclase, (5) pyroxene, (6) micrographic quartz and orthoclase, (7) orthoclase, (8) quartz.

\section{VARIETIES}

General description.-Differentiation of the diabase magma has given rise to numerous well defined varieties in which the minerals occur in widely varying proportions. Thus (1) normal diabase is the prevalent pyroxene-feldspar aggregate already described; (2) feldspathic diabase, or anorthosite, consists chiefly of plagioclase feldspar; (3) quartz diabase contains abundant quartz, largely in micrographic intergrowth with orthoclase; (4) micropegmatite consists essentially of the graphic intergrowth of quartz and orthoclase; (5) aplite is a dense granular quartzorthoclase rock; (6) hypersthene diabase carries much hypersthene, which replaces in part the common monoclinic pyroxene; (7) olivine diabase has abundant olivine; (8) basaltic diabase, or basalt, is the dense black facies, some of which is vesicular and has a glassy ground-mass; (9) olivine basalt is the dense black variety, with abundant olivine.

Normal diabase.-Except near the contacts, the rock of the larger bodies, both sheets and cross-cutting masses, is for the most part medium fine to coarse grained and ranges in color from light gray and pinkish to 
lark grayish black. It is cornposed chiefly of greenish black pyroxene and white to gray plagioclase feldspar, with scattered grains of magnetite. In the coarser varieties the presence of orthoclase can generally be recognized in the hand specimen-locally in large amount-and visible quartz is commonly associated with it.

While there is some variation in the proportions of the pyroxene and feldspar, in many places they are approximately equal or one is not greatly in excess of the other. As a rule, the elongated feldspars are in contact with one another and the pyroxene in broader detached areas fills the spaces betwcen, constituting the typical diabasic texture. Less commonly the pyroxene is in such excess that the feldspars are more or less isolated in it, producing an ophitic texture. Grains and crystals of magnetite are included in both of these constituents and minute needle-like crystals of apatite occur as inclusions in all three. In nearly all specimens of the normal granular diabase micrographic intergrowths of quartz and orthoclase, with here and there also separate grains of these minerals, occupy small scattered areas among the elongated plagioclase laths. Not uncommonly a little biotite accompanies the pyroxene and magnetite, but small grains of pyrite and chalcopyrite are rare.

Feldspathic diabase, or anorthosite.-With the decrease of pyroxene, plagioclase becomes the dominant constituent of the rock. Pyroxene constitutes only about one-third and one-fourth of the rock, respectively, in specimens from near the eastern border of the main sheet east of Gettysburg and from the cross-cutting body that extends westward from it at the extreme southern border of the Fairfield quadrangle, 6 miles southwest of Gettysburg. At the latter locality the pyroxene is reduced to small grains and stringers among the relatively large feldspars, and the rock from both places is light gray to nearly white in color. Both contain magnetite and minute needles of apatite, but a little micropegmatite and a few scattered grains of quartz are found only in the latter. A remarkable association of extreme types is shown in specimens from the thin sheet $11 / 4$ miles southeast of Bendersville, where a rock having the megascopic characters of this feldspathic facies is closely accompanicd by the dense black basaltic type. A similar basalt from the same sheet threefourths of a mile farther east proves on examination with the microscope to be an olivine basalt.

Quartz diabase.-Micrographic quartz-orthoclase and plagioclase in approximately equal parts are the chief constituents of coarse-grained white, pink, and gray facies of the diabase in many localities. Pyroxene forms less than one-half and even less than one-fourth of the rock, with the usual small amount of magnetite and apatite. Quartz and orthoclase are 
commonly present also in separate grains. Numerous large grains of quartz are distinctly visible in several places, and in some specimens crystal terminations are seen in miarolitic cavities. Scattered grains of yellowish brown titanite are readily recognized in the coarse-grained white variety from the Biggs quarry, 1 mile south of Gettysburg. In this rock, also, the pyroxene is in the form of lath-shaped prisms up to 20 millimeters in length and a little biotite is visible. Decrease in plagioclase results in the transition to micropegmatite, and in some localities aplite is also associated with this facies.

Micropegmatile.-Consisting chiefly of quartz and orthoclase in micrographic intergrowth, this variety of pink to pinkish gray rock is much like the quartz diabase described above and shows gradations into it. The texture ranges from medium fine to coarse grained. Quartz and orthoclase in large separate grains are common constituents, while plagioclase is very subordinate and in some the pyroxene is almost entirely lacking. This type is well represented at several localities.

Aptite.-Associated with quartz diabase and micropegmatite is an aplitic facies of the rock consisting of a fine-grained aggregate of quartz and orthoclase, with subordinate plagioclase, shreds of pyroxene, and scattered grains of magnetite and apatite. Numerous irregular grains of titanite occur in the pink aplite, which is abundant in the cross-cutting borly i miles northeast of Gettysburg.

Hypersthene diabase.-Both orthorhombic and monoclinic pyroxenes are present in hypersthene diabase. Several specimens from the lower and middle portions of the Gettysburg sheet and one from the apophysis 6 miles to the northeast contain hypersthene in varying proportions, from about one-fifth to more than one-half the total pyroxenes, and in all cases these minerals exceed the feldspars in amount. A little biotite is found also in all of them, but the micrographic intergrowth of quartz and orthoclase is a constituent of only one specimen. The hypersthene shows the usual pleochroism in shades of red and green. A specimen of olivine diabase from near the bottom of the Gettysburg sheet also contains a little of this mineral.

Olivine diabase.--Fresh rounded grains of olivine of all sizes, from minute granules to about the average texture of the rock, constitute about 10 per cent of the bulk of the olivine diabase above referred to from the Gettysburg sheet. The rock is of medium fine texture and of dark brownish black color. Hypersthene is present and a small amount of biotite, but micropegmatite and quartz are absent. Otherwise the rock is similar in all respects to normal diabase. 
Basaltic diabuse, or basalt.-Basaltic diabase, fine grained to dense and nearly black, constitutes the dikes and thin sheets and the contact facies of the larger masses. Scattered phenocrysts of pyroxene and less commonly of feldspar and olivine are found in many places; otherwise the texture is entirely aphanitic. This facies of the rock, particularly where a glassy base persists, is essentially a basalt similar to that which constitutes the lava flows of the same magma in the Watchung Mountains of New Jersey. In the holocrystalline type the texture is prevailingly diabasic, with pyroxene generally in excess of feldspars. Abundant magnetite, uniformly disseminated through the rock in the form of minute granules, accounts in large measure for the black color. - Locally, larger grains and crystals of magnetite occur, some in beautiful skeleton form. Minor accessories include a little biotite, minute needles of apatite, and scattered phenocrysts of olivine in places or serpentine pseudomorphs of this mineral.

Olivine basalt.-Basaltic diabase grades into typical basalt, as stated above, and this occurs both with and without scattered grains of olivine. In places this mineral is so abundant as to constitute typical olivine basalt. The thin sheet east of Chestnut Hill is also vesicular at the top. A dark-brown glassy base, thickly sprinkled with granules and skeleton crystals of magnetite, is abundant in a specimen from a thin sheet southeast of Bendersville. In places the magnetite is so abundant as to render the glass black and opaque.

\section{PETROGRAPHIC DETAILS}

Pyroxene.-The common monoclinic pyroxene is nearly black in the hand specimen, but is pale green to almost colorless in thin sections. Exceptionally it exhibits a slight pleochroism in shades of pale green and light greenish yellow. Having generally crystallized later than the feldspars, it has no crystal boundaries. The elongated prisms in some coarse pegmatitic varieties and the scattered phenocrysts in some of the basaltic facies are exceptions. Common types of twinning are those parallel to (1) the orthopinacoid (100), producing paired halves; and (2) the basal pinacoid (001), in repeated thin lamellæ, probably due to stresses in the rock. Magnetite and biotite, where it occurs, are common inclusions, and here and there minute apatite crystals, although the latter is more abundant in the feldspars and quartz.

Some degree of alteration to uralitic amphibole or serpentine, less commonly to chlorite, is almost universal. One of these secondary products usually predominates almost to the total exclusion of the others, although all of them are found together in some sections. The uralite in turn 
alters to serpentine or chlorite. The pyroxene contains but little alumina, and that required for chlorite is undoubtedly derived in the main from accompanying feldspars. This is further shown by the fact that scales of chlorite have developed in the feldspars, as well as in minute veinlets that intersect all the minerals, proving the migration of its constituents. The secondary minerals after pyroxene are commonly darkened by granules, and in some places trellis-like skeleton crystals, of magnetite. Locally these are so abundant as to blacken the whole space occupied by the original pyroxene. Calcite is rare among the decomposition products, even in the most altered specimens.

Hypersthene.-With the exception of pleochroism and parallel extinction, hypersthene has the general appearance and characteristics of the monoclinic pyroxene. It alters to uralitic amphibole and serpentine, although, as a rule, it is fresher than the monoclinic pyroxene.

Plagioclase feldspar.-Generally the plagioclase forms the well known lath-shaped or rod-shaped crystals, but in some of the rock of coarser texture, with much quartz and orthoclase, it is much less elongated and the texture approaches the granitic. Terminal planes are commonly lacking and twinning lamellæ are universal, commonly according to the albite law, although pericline and carlsbad twinning are also observed. Zonal structure is rather common and, fringing the extreme acid borders, a graphic intergrowth of orthoclase and quartz generally fills some of the smaller interstices. Extinction angles correspond generally to an andesine-labradorite. Apatite, magnetite, and olivine occur as inclusions. The plagioclase most in evidence in the microscopic study seems to be largely andesine-labradorite, but chemical analyses of similar material from other localities shows the presence of a much wider range of feldspars.

Alteration gives rise chiefly to a confused fine scaly aggregate with high double refraction, apparently sericite (paragonite?), with a little kaolin in places. With migration of iron and magnesia from the pyroxene, chlorite is developed, as described above.

Orthoclase, microcline, quartz.--Quartz and orthoclase in micrographic intergrowth are very common, but separate grains large enough to be seen in the hand specimen are generally present in the lighter colored coarsegrained varieties of the rock. In these, areas of micropegmatite 3 or 4 millimeters in diameter are so abundant in places as to constitute threefourths of the rock or more. Microcline is comparatively rare. Orthoclase is commonly much more altered than plagioclase-generally to a chalky kaolin-like substance, but in places to sericitic aggregates. 
Magnetite.-Magnetite conmonly forms 5 per cent of the rock or less. The grains and crystals are generally smaller than the associated pyroxenes and feldspars, and some of them form inclusions in both of these constituents. Lattice-like and dendritic skeletons are common. Some of these are beautiful aggregates of minute octahedrons. Secondary magnetite is commonly abundant among the alteration products of pyroxene. Masses that are molded irregularly about and among the plagioclase crystals are doubtless of this character-at least in part.

Biotite.-Small amounts of biotite are scattered through the finer grained contact facies and larger irregular flakes are clustered about the magnetite and pyroxene of the coarser grained rock. In places it is apparently secondary after pyroxene. It is altered in part to chlorite. The great bulk of the normal diabase contains little or no biotite.

Olivine.-Olivine occurs in the finer grained rock chiefly as scattered phenocrysts, which are generally altered, in part at least, to yellow or yellowish brown serpentine. Somewhat rounded and irregular grains are common, but some have crystal outlines.

A patite.-Apatite in minute crystals occurs in all varieties of the diabase and forms inclusions in all the other constituents, but chiefly in the feldspars and quartz. It forms slender hexagonal prisms, with maximum dimensions of $0.0 \%$ by 2.0 millimeters, although most of them are much smaller and appear needle-like under the microscope.

Pyrite and chalcopyrite.-Small grains of pyrite and chalcopyrite are occasionally seen in hand specimens of the diabase, but they are rarely recognized in the thin sections.

Titanite.-Grains and crystals of itanite are abundant in the pink aplite facies of the apophysis 6 miles northeast of Gettysburg and in the coarse white quartz diabase south of Gettysburg. The latter rock contains elongated prisms of pyroxene and radial clusters of epidote in crystals up to 15 millimeters long.

Tachylite, basalt glass.-Dark-brown glass forms an abundant groundmass in the black olivine basalt southeast of Bendersville. It is thickly sprinkled with granules and crystals of magnetite and in places is black and opaque with them. The olivine basalt east of Chestnut Hill has a vesicular crust 8 millimeters thick, which is probably glass in part; but the dense rock immediately adjacent to this crust is entirely crystalline.

\section{CHEMIOAL OOMPOSITION}

Composition of various types of diabase.-Analyses of Triassic diabase from various parts of the Atlantic slope agree in general character, but show considerable variation corresponding to their diverse mineral 
constitution, as illustrated by the examples in the following table. It is to be regretted that none of the rocks of this immediate district have been analyzed; but the following analyses from other areas are given here as a suggestion of the variations that probably occur in the rocks of the Gettysburg area. No analyses of the extreme quartz-orthoclase typesaplite and micropegmatite-are available from any part of the region. These would undoubtedly show much higher silica and alkalies and lower lime, iron, and magnesia than any of the examples quoted here.

Analyses of various Types of Triassic Diabase ${ }^{3}$

\begin{tabular}{|c|c|c|c|c|c|c|c|}
\hline & 1 & 2 & $\mathbf{3}$ & 4 & 5 & 6 & 7 \\
\hline $\mathrm{SiO}_{2} \ldots \ldots \ldots \ldots \ldots$ & 60.05 & 56.78 & 51.68 & 46.87 & 55.31 & 50.88 & 49.02 \\
\hline $\mathrm{Al}_{2} \mathrm{O}_{3} \ldots \ldots \ldots \ldots$ & 11.88 & 14.33 & 15.87 & 13.36 & 13.64 & 13.17 & 10.14 \\
\hline $\mathrm{Fe}_{2} \mathrm{O}_{3} \ldots \ldots \ldots \ldots$ & 3.22 & 5.76 & 1.46 & 9.79 & 0.52 & 1.11 & 1.54 \\
\hline $\mathrm{FeO} \ldots \ldots \ldots \ldots$ & 10.21 & 9.27 & 8.43 & 2.71 & 8.49 & 9.66 & 10.46 \\
\hline MgO $\ldots \ldots \ldots \ldots \ldots$ & 0.85 & 1.58 & 7.84 & 4.35 & 12.73 & 13.05 & 17.25 \\
\hline $\mathrm{CaO} \ldots \ldots \ldots \ldots$ & 4.76 & 5.26 & 11.08 & 14.70 & 12.41 & 10.19 & 8.29 \\
\hline $\mathrm{Na}_{2} \mathrm{O} \quad \ldots \ldots \ldots \ldots$ & 4.04 & 3.43 & 1.86 & 4.64 & 1.40 & 1.17 & 1.59 \\
\hline $\mathrm{K}_{2} \mathrm{O} \ldots \ldots \ldots \ldots$ & 2.10 & 1.75 & 0.34 & 2.01 & 0.32 & 0.31 & 0.40 \\
\hline $\mathrm{H}_{2} \mathrm{O}+\ldots \ldots \ldots \ldots$ & 0.66 & 0.10 & 0.15 & $\cdots$ & $\ldots$ & 0.14 & 0.59 \\
\hline $\mathrm{H}_{2} \mathrm{O}-\ldots \ldots \ldots \cdots$ & 0.21 & 0.33 & 0.16 & $\cdots$ & $\ldots$ & $\ldots$ & 0.16 \\
\hline $\mathrm{TiO}_{2} \ldots \ldots \ldots \ldots$ & 1.74 & 1.44 & 0.72 & 1.98 & tr. & $\cdots$ & 0.99 \\
\hline$P_{2} O_{5} \ldots \ldots \ldots \ldots \ldots$ & 0.52 & 0.36 & 0.12 & $\cdots \cdot$ & tr. & $\ldots$ & 0.11 \\
\hline MnO....$\ldots \ldots$ & 0.28 & 0.25 & 0.15 & $\cdots$ & tr. & tr. & 0.16 \\
\hline & & 00.64 & 99.86 & 100.41 & 100.82 & 99.67 & \\
\hline $1 . \cdots$ & 2.872 & $\cdots \cdot$ & $\ldots$ & $\ldots$ & $\ldots$ & $\ldots$ & 3.152 \\
\hline
\end{tabular}

1. Quartz diabase (dacose, II. 4. 2.4). Pennsylvania Railroad tunnel through the Palisades, 400 feet from the west portal, Homestead, New Jersey.

2. Quartz diabase (tonalose, II. 4. 3.4). About 420 feet from the upper surface of the sheet, Rocky Hill, New Jersey.

3. Diabase (auvergnose, III.5.4.3). Rocky Ridge, Maryland.

4. Diabase (kilauose, III. 5. 2.4). Birdsboro, near Norristown, Pennsylvania.

5. Hypersthene diabase (auvergnose, III. 5. 4. 3). The Twins, Culpeper County, Virginia.

6. Olivine-hypersthene diabase (auvergnose, III. 5. 4. 3). The Twins, Culpeper County, Virginia.

7. Otivine diabase (palisadose, IV. $1^{2} .1^{2} .2$ ). The Palisades, Englewood Cliffs, New Jersey.

${ }^{3}$ Numbers 1 and 7 , by R. B. Gage (Ann. Rept. Geol. Survey of New Jersey for 1907, p. 121) ; 2, by A. H. Phillips (Amer. Jour. Sci., vol. viii, 1899, p. 267) ; 3, by A. E. Schneider (Bull. U. S. Geol. Survey, No. 148, p. 90); 4, by H. Fleck (19th Ann. Rept. U. S. Geol. Survey, vol. vi, cont., p. 222) ; 5 and 6, by W. G. Brown (Bull. Geol. Soc. Am., vol. 2, 1898, p. 346). 
Composition of the pyroxene.-Most analyses of pyroxene from the Triassic diabase show a moderately aluminous diopside. As compared with augite, there is a great excess of ferrous oxide and magnesia over lime, alumina, and ferric oxide. Analyses 1 to 4 in the following table may be regarded as approximately equivalent to a combination of diopside with common aluminous augite in proportions ranging from about $3: 1$ to $1: 1$, with small amounts of alkalies, indicating the presence of the acmite molecule. Number 5 approaches more nearly a typical augite.

Analyses of l'yroxene from Triassic Diabase"

\begin{tabular}{|c|c|c|c|c|c|}
\hline & $\mathbf{1}$ & 2 & 3 & 4 & $\mathbf{5}$ \\
\hline $\mathrm{SiO}_{2} \ldots \ldots \ldots \ldots \ldots \ldots \ldots \ldots \ldots \ldots$ & 47.72 & 48.54 & 50.71 & 48.83 & 49.33 \\
\hline $\mathrm{Al}_{2} \mathrm{O}_{3} \ldots \ldots \ldots \ldots \ldots \ldots \ldots$ & 3.44 & 5.50 & 3.55 & 4.41 & 9.15 \\
\hline $\mathrm{Fe}_{2} \mathrm{O}_{3} \ldots \ldots \ldots \ldots \ldots \ldots \ldots \ldots \ldots$ & 5.93 & 2.77 & $\ldots$ & $\ldots$ & 0.27 \\
\hline $\mathrm{FeO} \quad \ldots \ldots \ldots \ldots \ldots \ldots \ldots \ldots$ & 18.34 & 21.25 & 15.30 & $9.00 *$ & 9.05 \\
\hline MgO $\ldots \ldots \ldots \ldots \ldots \ldots \ldots \ldots$ & 12.89 & 7.67 & 13.63 & 17.11 & 14.58 \\
\hline $\mathrm{CaO} \ldots \ldots \ldots \ldots \ldots \ldots \ldots$ & 11.40 & 10.97 & 13.35 & 20.51 & 16.36 \\
\hline $\mathrm{Na}_{2} \mathrm{O} \quad \ldots \ldots \ldots \ldots \ldots \ldots \ldots \ldots \ldots$ & 0.86 & \multirow{2}{*}{3.10} & \multirow{2}{*}{$1.48^{\circ}$} & … & 0.55 \\
\hline $\mathrm{K}_{2} \mathrm{O} \quad \ldots \ldots \ldots \ldots \ldots \ldots \ldots \ldots \ldots \ldots$ & 0.37 & & & $\ldots$ & 0.19 \\
\hline Mno $\ldots \ldots \ldots \ldots \ldots \ldots \ldots \ldots$ & $\ldots$ & $\ldots$ & 0.81 & $\ldots$ & \\
\hline \multirow[t]{2}{*}{ Ign. $\ldots \ldots \ldots \ldots \ldots \ldots \ldots \ldots$} & 0.00 & 0.82 & 1.17 & $\ldots$ & 0.25 \\
\hline & 00.95 & 100.62 & 100.00 & 99.86 & $99 . ?$ \\
\hline
\end{tabular}

1. From coarse-grained diabase from near the middle of the sheet, Rocky Hill, New Jersey. Pyroxene constitutes $\mathbf{4 1}$ per cent of the rock.

2. From quartz diabase 420 feet from the upper surface of the sheet, Rocky Hill, New Jersey. Pyroxene constitutes 45.6 per cent of the rock.

3. From diabase sheet, West Rock, New Haven, Connecticut.

4. From olivine diabase, near Chatham, Virginia.

5. From hypersthene diabase, Culpeper County, Virginia.

Composition of the feldspars.-The composition of the feldspars shows a wide range, corresponding in general to the differentiations as shown by the mineral constitution of the rock. Thus in the following table analyses $1 \mathrm{a}$ to $1 \mathrm{~d}$, from quartz diabase, range from nearly purc alhite to andesine, associated with decreasing proportions of orthoclase; 2 and 3 show andesine-labradorite to labradorite from normal diabase, and 4 a more basic labradorite from hypersthene diabase. From the high percentages of silica, it is evident that free quartz was present in some of the specimens. Thus there is an excess of 20.6 per cent in 1a, 26 per cent in $1 \mathrm{~b}, 11$ per cent in $3 \mathrm{~b}$, and smaller amounts in the others.

'Numbers 1 and 2, by A. H. Phillips (Amer. Jour. Scl., vol. vili, 1899, p. 267) ; 3, by G. W. Hawes (Amer. Jour. Sci., vol. ix, 1875, p. 185) ; 4, by T. L. Watson (Amer. Geol., vol. xxil. 1898, p. 98) ; 5, by W. G. Brown (Bull. Geol. Soc. Am., vol. 2, 1891, p. 344)

* Determined as $\mathrm{Fe}_{2} \mathrm{O}_{3} 10.01$.

s By difference. 


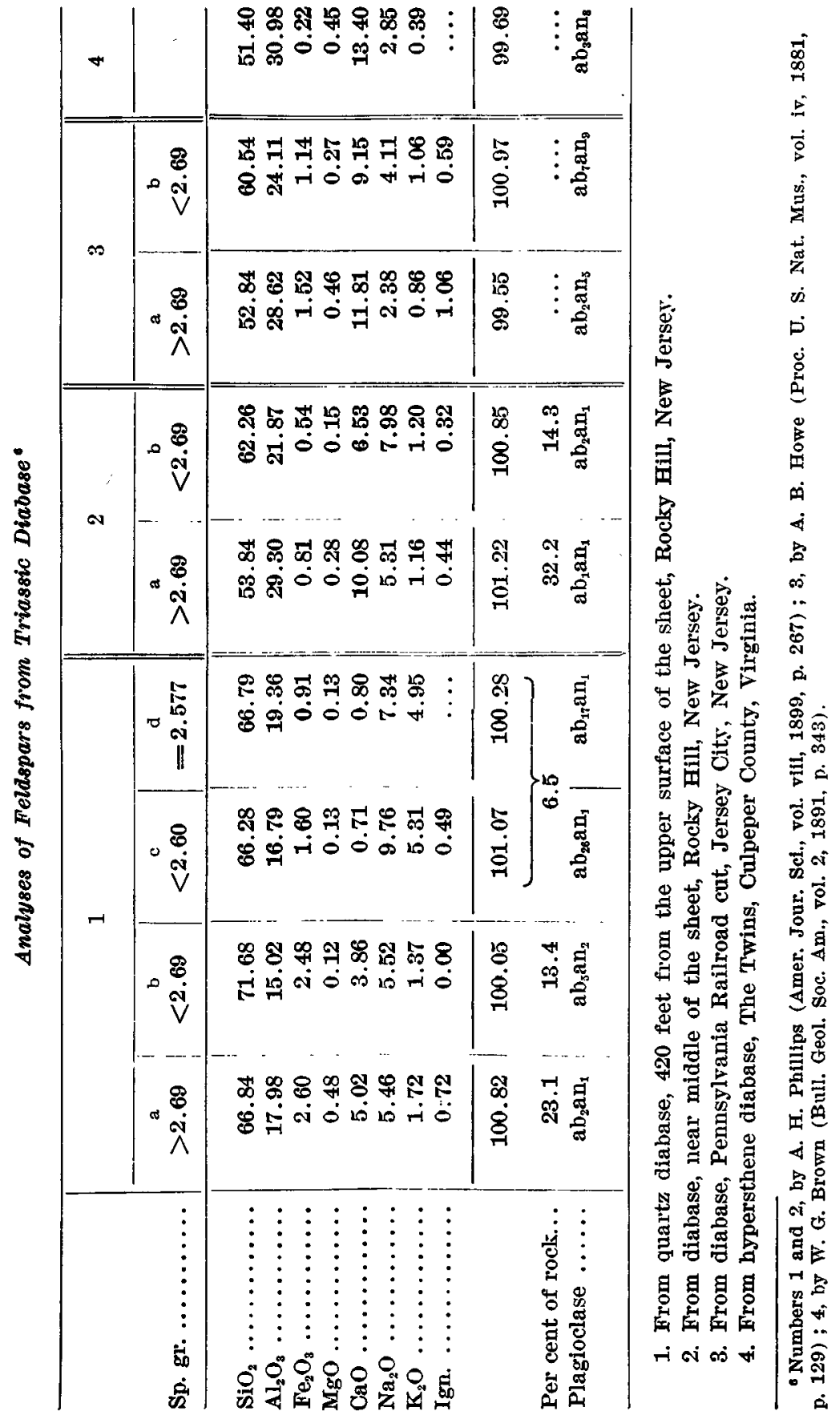




\section{MINERAL COMPOSITION}

The proportions of the various mineral constituents in certain facies of the Triassic diabase have been determined from thin sections by the Rosiwal method, with the results that are given in the following table. No measurements have been made on aplite and micropegmatite, some specimens of which are composed almost exclusively of quartz and orthoclase in approximately equal amounts.

Mineral Composition of certain Facies of Triassic Diabase

\begin{tabular}{|c|c|c|c|c|c|c|}
\hline & (1) & (2) & (3) & (4) & (5) & (6) \\
\hline Quartz $\ldots \ldots \ldots \ldots \ldots \ldots \ldots$ & 19 & 7 & . & .. & . & .. \\
\hline Feldspar $\ldots \ldots \ldots \ldots \ldots \ldots$ & 44 & 42 & 37 & 20 & 38 & 18 \\
\hline Pyroxene...$\ldots \ldots \ldots \ldots$. & 27 & 34 & 59 & 73 & 46 & 58 \\
\hline Biotite..$\ldots \ldots \ldots \ldots \ldots \ldots$ & $\mathbf{3}$ & .. & .. & 1 & 1 & $\mathbf{1}$ \\
\hline Olivine $\ldots \ldots \ldots \ldots \ldots \ldots$ & .. & .. & 1 & 4 & 13 & 20 \\
\hline Magnetite $\ldots \ldots \ldots \ldots \ldots \ldots$ & 7 & 17 & $\mathbf{3}$ & 2 & 2 & $\mathbf{3}$ \\
\hline
\end{tabular}

1. Quartz diabase, Pennsylvania Railroad tunnel through the Palisades, 400 feet from the west portal, Homestead, New Jersey.

2. Quartz diabase, 420 feet east of the station platform, Marion Station, Jersey City, New Jersey.

3. Diabase, the Palisades; Englewood Cliffs, New Jersey.

4. Diabase, the Palisades, near West Shore Railroad ferry, Weehawken, New Jersey.

5. Olivine diabase associated with number 4 .

6. Olivine diabase, the Palisades, horseshoe curve of the trolley line, Edgewater, New Jersey. 
. 